\title{
Poetry and its Contexts in Eleventh-century Byzantium
}

\author{
Edited by \\ FLORIS BERNARD \\ Ghent University, Belgium \\ KRISTOFFEL DEMOEN \\ Ghent University, Belgium
}


All rights reserved. No part of this publication may be reproduced, stored in a retrieval system or transmitted in any form or by any means, electronic, mechanical, photocopying, recording or otherwise without the prior permission of the publisher.

Floris Bernard and Kristoffel Demoen have asserted their right under the Copyright, Designs and Patents Act, 1988, to be identified as the editors of this work.

Published by

Ashgate Publishing Limited

Wey Court East

Union Road

Farnham

Surrey, GU97PT

England

Ashgate Publishing Company

Suite 420

101 Cherry Street

Burlington

VT 05401-4405

USA

www.ashgate.com

\section{British Library Cataloguing in Publication Data}

Poetry and its contexts in eleventh-century Byzantium.

1. Byzantine poetry--History and criticism. 2. Byzantine

Empire--Intellectual life.

I. Bernard, Floris. II. Demoen, Kristoffel.

881'.0209-dc23

\section{Library of Congress Cataloging-in-Publication Data}

Bernard, Floris.

Poetry and its contexts in eleventh-century Byzantium / Floris Bernard and

Kristoffel Demoen.

p. cm.

Includes bibliographical references and index.

ISBN 978-1-4094-4071-0 (hardcover) -- ISBN 978-1-4094-4072-7 (ebook)

1. Byzantine poetry--History and criticism. I. Demoen,

Kristoffel. II. Title.

PA5150.B47 2012

881 '.0209--dc23

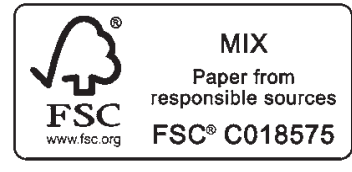

Printed and bound in Great Britain by the MPG Books Group, UK. 


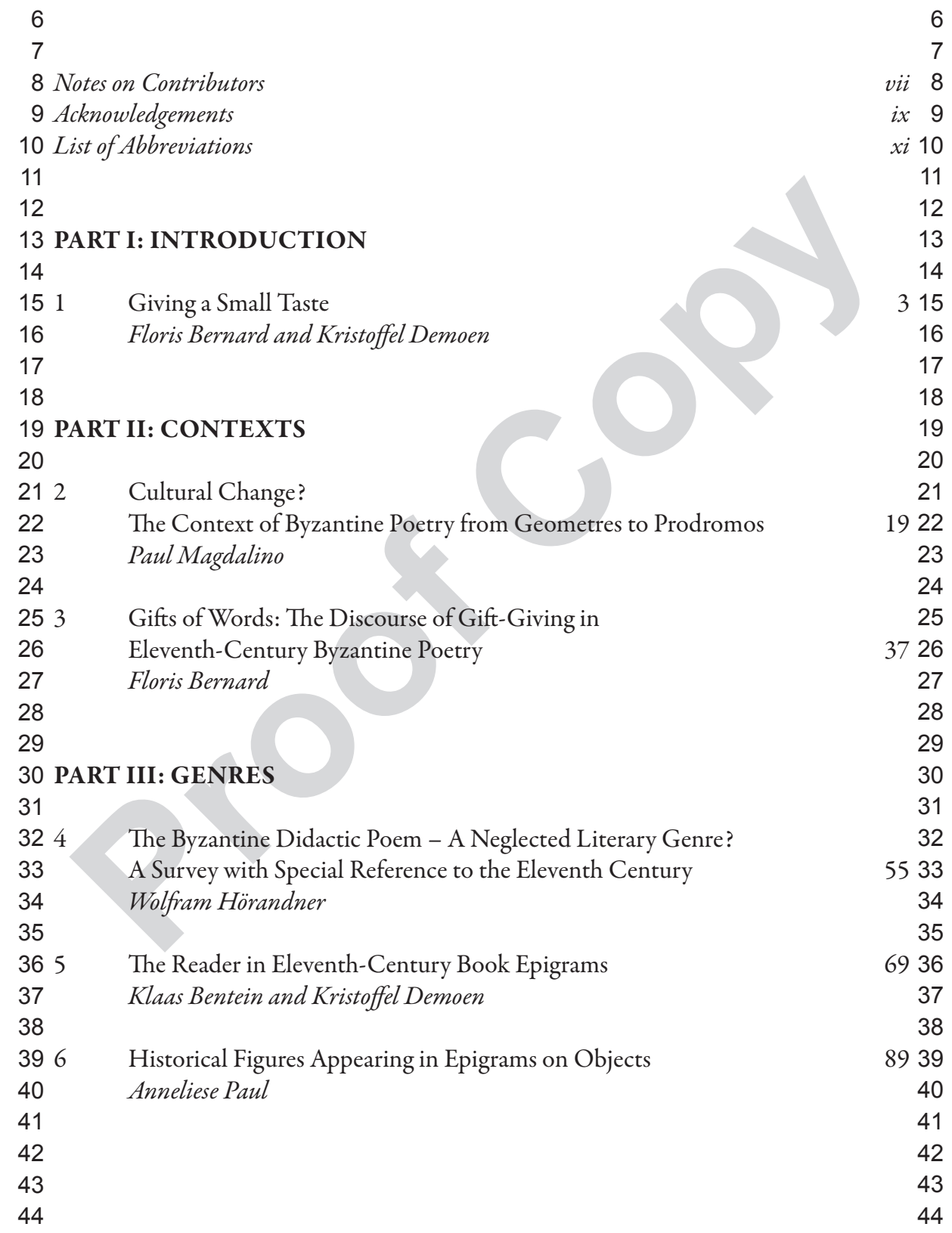


1 PART IV: AUTHORS 1

2

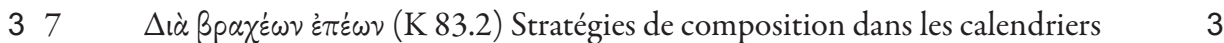

4 métriques de Christophore Mitylenaios $\quad 115 \quad 4$

$5 \quad$ Lia Raffaella Cresci 5

626

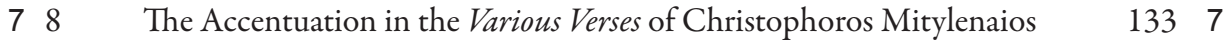

$8 \quad$ Marc De Groote 8

929

109 On the Inscriptional Versions of the Epigrams of 10

11 Christophoros Mitylenaios $\quad 14711$

12 Andreas Rhoby 12

$13-13$

1410 A Few Thoughts on the Influence of Classical and Byzantine Poetry on the 14

15 Profane Poems of Ioannes Mauropous $\quad 15515$

$16 \quad$ Claudio De Stefani 16

$17 \quad 17$

1811 The Dioptra of Philippos Monotropos: Didactic Verses or Poetry? $\quad 18118$

19 Eirini Afentoulidou-Leitgeb 19

$20 \quad 20$

$21 \quad 21$

22 PART V: BOOKS 22

$23 \quad 23$

2412 The Perils of Travel: Mark the Monk and Bodl. E.D. Clarke 15

25 Marc Lauxtermann 25

$26 \quad 26$

2713 Poésies à la marge, réflexions personnelles? 27

28 Quelques observations sur les poésies du Parisinus graecus $1711 \quad 20728$

29 Paolo Odorico 29

$30 \quad 30$

$31 \quad 31$

32 Bibliography $\quad 22532$

33 Index of Authors and Texts $\quad 23733$

34 General Index $\quad 23934$

$35 \quad 35$

$36 \quad 36$

$\begin{array}{ll}37 & 37\end{array}$

$38 \quad 38$

$39 \quad 39$

$40 \quad 40$

$41 \quad 41$

$42 \quad 42$

$43 \quad 43$

$44 \quad 44$ 